\title{
Risk factors for the lack of adherence to breastfeeding
}

\author{
Karine Corcione Turke ${ }^{*}$ (1), Lívia Restani dos Santos ${ }^{1}$ (D) Letícia Santos Matsumura ${ }^{1}$, \\ Roseli Oselka Saccardo Sarni ${ }^{1}$
}

\section{SUMMARY}

OBJECTIVE: To evaluate the prevalence of breastfeeding in a metropolitan region in Brasil and to identify factors influencing the lack of adherence to exclusive breastfeeding for 6 months and total breastfeeding for 2 years.

METHODS: In this cross-sectional study, demographic and socioeconomic characteristics of mothers and children in pediatric outpatient clinics were analyzed. Logistic regression was performed using the backward stepwise method to analyze factors associated with the lack of breastfeeding compliance.

RESULTS: In total, 385 mothers who visited the pediatric outpatient clinics were included. Among the mothers, 38.44\% reported exclusive breastfeeding for $>6$ months and $22.6 \%$ reported total breastfeeding for 2 years or more. The predictive factors for the lack of adherence to exclusive breastfeeding for 6 months included single mothers ( $O R=1.976 ; 95 \% \mathrm{Cl} 1.245-3.135 ; p=0.004)$, use of a pacifier $(O R=2.25 ; 95 \% \mathrm{Cl} 1.436-3.524 ; \mathrm{p}<0.001)$, and low birth weight $(\mathrm{OR}=2.21 ; 95 \% \mathrm{Cl} 1.192-4.102 ; \mathrm{p}=0.012)$. Predictive factors for the lack of adherence to total breastfeeding for 2 or more years included use of a pacifier $(\mathrm{OR}=4.82 ; 95 \% \mathrm{Cl} 2.722-8.54 ; \mathrm{p}<0.001)$, planned pregnancy $(\mathrm{OR}=0.51 ; 95 \% \mathrm{Cl} 0.305-0.875 ; \mathrm{p}=0.014)$, and breastfeeding in the first hour of life $(\mathrm{OR}=0.36 ; 95 \% \mathrm{Cl} 0.208-0.641 ; \mathrm{p}<0.001)$. CONCLUSIONS: The prevalence of exclusive breastfeeding for 6 months and total breastfeeding for 2 years or more was insufficient in the studied population. Several factors were associated with the lower duration of exclusive breastfeeding and total breastfeeding. The use of a pacifier and no breastfeeding in the first hour were preventable factors associated with both modalities.

KEYWORDS: Breast feeding. Risk factors. Child.

\section{INTRODUCTION}

Breast milk is the best and most appropriate source of nutrients, protective factors, and emotional strengthening for the infant. It plays a fundamental role in the ideal health conditions of a child with favorable repercussions throughout life, especially when offered as an exclusive food until the age of 6 months ${ }^{1}$.

Children who are breastfed for longer periods have lower morbidity and mortality related to infectious diseases, lower risk of dental malocclusion, greater intelligence, and possibly lower risk of developing overweight and long-term diabetes ${ }^{2}$.

Additionally, breastfeeding strengthens the maternal bond with the child ${ }^{3}$. Breastfeeding also protects mothers by preventing breast cancer, improving inter-gestational time, and possibly reducing the risk of diabetes and ovarian cancer $^{2}$.
Breastfeeding has benefits such as strengthening the bond with the child ${ }^{1}$ and reducing infant mortality ${ }^{4 . \text { According to }}$ the World Health Organization (WHO) $)^{5}$, breastfeeding should be exclusive until the age of 6 months and supplemented with other foods until the age of 2 years or more.

Exclusive breastfeeding (EBF) and total breastfeeding times have been insufficient in Brasil and other countries 5 . The prevalence of total breastfeeding for 2 years or more in Brasil was $31.8 \%$ in 2013, and the worldwide prevalence was $45 \%$ in $2017^{6,7}$.

The prevalence of exclusive breastfeeding for 6 months or more in all Brasilian capitals and Federal Districts was $41.3 \%$ in 2008. The median duration of EBF was 54.1 days (1.8 months), and the median total breastfeeding duration was 341.6 days

${ }^{1}$ Centro Universitário Saúde ABC - Santo André (SP), Brasil.

*Corresponding author: karineturke@hotmail.com

Conflicts of interest: the authors declare there is no conflicts of interest. Funding: none.

Received on October 13, 2020. Accepted on October 30, 2020. 
(11.2 months $)^{6,8,9}$. The global prevalence of EBF was $35.7 \%$ in 2013, while the WHO has proposed a target prevalence of $50 \%$ by $2025^{6,9}$.

Several factors, including socioeconomic conditions of the family, no breastfeeding within the first hour of life, and reduced access to education, are associated with shorter duration of breastfeeding ${ }^{10,11}$. Unconfirmed associations have been suggested with respect to factors that reduce EBF and total breastfeeding durations ${ }^{12}$.

The present study aimed to identify factors associated with the lack of adherence to EBF for 6 months and total breastfeeding for up to 2 years of age and evaluate the prevalence of these modalities in a metropolitan region in Brasil.

\section{METHODS}

\section{Study design}

Cross-sectional and observational study

\section{Ethical aspects}

The study was approved by the Ethics and Research Committee (CAAE 79849817.7.0000.0082). It was performed in accordance with the regulations of the Declaration of Helsinki.

\section{Participants}

Mothers whose children were cared for by the pediatric outpatient clinics of Faculdade de Medicina do $A B C$, in Santo André, were selected and interviewed in 2018. The Free and Informed Consent Term was signed by all included mothers. Mothers with breastfeeding children, mothers with children over 12 years of age, and mothers under 18 years of age were excluded.

\section{Variables}

Demographic data of mothers included color, education, marital status, family income, and number of people living in the house. Data related to gestational antecedents included number of children and abortions, type of delivery and complications, whether the pregnancy was planned, and age at the time of delivery.

Data related to children included date of birth, weight at birth, gestational age, and use of a pacifier. Mothers were asked about breastfeeding in the first hour of life and the duration of $\mathrm{EBF}$ and total breastfeeding in months.

Dependent variables included EBF for $<6$ months and total breastfeeding for $<2$ years.

\section{Sample size calculation}

Sample size calculation was based on a study of risk factors for non-adherence to EBF conducted in the city of São Paulo. Considering maternal age under 20 years with a $19.6 \%$ prevalence of EBF (prevalence ratio of 0.53), the ideal sample size was 224. Considering the condition of not working away from home with a $28.2 \%$ prevalence of $\mathrm{EBF}$ (prevalence ratio of 1.8 ), the ideal sample size was 126 . Adding both these results, the ideal sample size was 350 participants $^{13}$.

\section{Statistical analysis}

Qualitative variables are presented as frequency and percentage, and quantitative variables are presented as mean and standard deviation or median and percentiles (p25-p75) depending on normality. The Shapiro-Wilk test was used to analyze data distribution.

To evaluate factors associated with EBF for $\leq 6$ months and with total breastfeeding for $<2$ years, logistic regression was performed using the stepwise regression method. The inclusion parameter for the variables was $\mathrm{p}<0.20$. Subsequently, variables with $\mathrm{p} \geq 0.05$ were excluded. The significance level was set at 5\%. All analyses were performed using the Stata ${ }^{\circ}$ software version 11.0 (StataCorp LLC, College Station, TX, USA).

\section{RESULTS}

\section{Sociodemographic data}

In total, 385 mothers were interviewed at the pediatric outpatient clinics of Faculdade de Medicina do $A B C$, in Santo André, Brasil. Most mothers were married (57.66\%), white (47.01\%), and had completed high school education (59.22\%). The median number of children, median number of abortions, and median number of people living in the same home were 2,0 , and 4 , respectively. The median family income was $R \$$ $1,547.00$ (Table 1). The current average maternal age was 35 years, and the average age of the mothers at the time of delivery was 28 years.

\section{Child data and birth}

The majority of deliveries took place at term (73.77\%), and most of them were performed via cesarean section $(53.51 \%)$. The median age of the mothers at the time of delivery was 28 years. Overall, $79.22 \%$ of mothers reported no complications at the time of delivery. Pregnancy was not planned in most mothers (54.03\%). Low birth weight and use of a pacifier were reported in 20.63 and $48.57 \%$ of children, respectively (Table 1). 
Table 1. Participants characteristics.

\begin{tabular}{|c|c|c|}
\hline Characteristics & $\mathbf{n}$ & $\%$ \\
\hline \multicolumn{3}{|l|}{ Marital status } \\
\hline Married & 222 & 57.66 \\
\hline Single & 163 & 42.34 \\
\hline \multicolumn{3}{|l|}{ Color } \\
\hline White & 181 & 47.01 \\
\hline Black & 52 & 13.51 \\
\hline Brown & 148 & 38.44 \\
\hline Yellow & 4 & 1.04 \\
\hline \multicolumn{3}{|l|}{ Education } \\
\hline Illiterate & 3 & 0.78 \\
\hline Incomplete elementary school & 55 & 14.29 \\
\hline Complete elementary school & 24 & 6.23 \\
\hline Incomplete high school & 29 & 7.53 \\
\hline Complete high school & 228 & 59.22 \\
\hline $\begin{array}{l}\text { Did not complete higher } \\
\text { education }\end{array}$ & 5 & 1.3 \\
\hline Completed higher education & 41 & 10.65 \\
\hline \multicolumn{3}{|l|}{ Time of delivery } \\
\hline Preterm & 71 & 18.44 \\
\hline Term & 284 & 73.77 \\
\hline Post-term & 30 & 7.79 \\
\hline \multicolumn{3}{|l|}{ Type of delivery } \\
\hline Cesarean section & 206 & 53.51 \\
\hline Normal or natural & 179 & 46.49 \\
\hline \multicolumn{3}{|l|}{$\begin{array}{l}\text { Complications } \\
\text { during delivery }\end{array}$} \\
\hline No & 305 & 79.22 \\
\hline Yes & 80 & 20.78 \\
\hline \multicolumn{3}{|l|}{ Low birth weight } \\
\hline No & 300 & 79.37 \\
\hline Yes & 78 & 20.63 \\
\hline
\end{tabular}

\section{Breastfeeding data}

In total, $57.14 \%$ of mothers reported breastfeeding within the first hour after giving birth. EBF for 6 months or more and breastfeeding for 2 years or more were reported by 38.44 and $22.6 \%$ of mothers, respectively (Table 1 ).

\section{Factors associated with exclusive breastfeeding $<6$ months and total breastfeeding duration $<2$ years}

Independent predictors for EBF for $<6$ months included marital status, gestational age, low birth weight, use of a pacifier, breastfeeding in the first hour of life, and unplanned pregnancy (Table 2).

Independent predictors for total breastfeeding duration $<2$ years included marital status, gestational age, use of a

\begin{tabular}{|c|c|c|}
\hline Characteristics & $\mathbf{n}$ & $\%$ \\
\hline \multicolumn{3}{|l|}{ Forceps } \\
\hline No & 365 & 94.81 \\
\hline Yes & 20 & 5.19 \\
\hline \multicolumn{3}{|l|}{ Used pacifier? } \\
\hline No & 198 & 51.43 \\
\hline Yes & 187 & 48.57 \\
\hline \multicolumn{3}{|l|}{ Planned pregnancy } \\
\hline No & 208 & 54.03 \\
\hline Yes & 177 & 45.97 \\
\hline \multicolumn{3}{|l|}{$\begin{array}{l}\text { Breastfeeding in the } \\
\text { first hour of life }\end{array}$} \\
\hline No & 165 & 42.86 \\
\hline Yes & 220 & 57.14 \\
\hline \multicolumn{3}{|l|}{$\begin{array}{l}\text { Exclusive breastfeeding } \\
\text { for more than } 6 \text { months }\end{array}$} \\
\hline No & 237 & 61.56 \\
\hline Yes & 148 & 38.44 \\
\hline \multicolumn{3}{|l|}{$\begin{array}{l}\text { Breastfeeding for more } \\
\text { than } 2 \text { years }\end{array}$} \\
\hline No & 298 & 77.4 \\
\hline \multirow[t]{2}{*}{ Yes } & 87 & 22.6 \\
\hline & Median & $\begin{array}{l}\text { Percentiles } \\
(25-75)\end{array}$ \\
\hline Number of children & 2 & $1-3$ \\
\hline Number of abortions & 0 & $0-0$ \\
\hline Age at the time of delivery. & 28 & $23-35$ \\
\hline $\begin{array}{l}\text { Number of people living in the } \\
\text { house }\end{array}$ & 4 & $3-5$ \\
\hline Family income & $\begin{array}{c}\mathrm{R} \$ \\
1,500.00\end{array}$ & $\begin{array}{c}\mathrm{R} \$ \\
900.00- \\
\mathrm{R} \$ \\
2,500.00\end{array}$ \\
\hline
\end{tabular}

pacifier, breastfeeding in the first hour, and unplanned pregnancy (Table 2).

The final predictors for EBF $<6$ months included marital status, use of a pacifier, breastfeeding in the first hour, and low birth weight. Single mothers had a higher risk of not completing EBF for 6 months than married ones (OR=1.976; 95\%CI $1.245-3.135 ; \mathrm{p}=0.004)$. Children who used a pacifier exhibited a two times greater risk of EBF for $<6$ months than those who did not use a pacifier $(\mathrm{OR}=2.25$; 95\%CI 1.436-3.524; $\mathrm{p}<0.001)$. Children with lower birth weight had a two times greater risk of $\mathrm{EBF}$ for $<6$ months $(\mathrm{OR}=2.21 ; 95 \% \mathrm{CI} 1.192$ 4.102; $\mathrm{p}=0.012$ ).

Mothers who breastfed in the first hour after birth had a lower risk of not adhering to EBF for 6 months (OR=0.048; 95\%CI $0.281-0.714 ; \mathrm{p}=0.001$ ). Women with planned pregnancies 
Table 2. Association between analyzed variables and duration of exclusive and total breastfeeding.

\begin{tabular}{|c|c|c|c|c|c|c|}
\hline & \multicolumn{2}{|c|}{ Exclusive breastfeeding } & \multirow{2}{*}{$p^{*}$} & \multicolumn{2}{|c|}{ Total breastfeeding } & \multirow{2}{*}{$p^{*}$} \\
\hline & $<6$ months & $\geq 6$ months & & $<2$ years & $\geq 2$ years & \\
\hline & \multicolumn{2}{|c|}{$\mathrm{n}(\%)$} & & \multicolumn{2}{|c|}{$\mathrm{n}(\%)$} & \\
\hline \multicolumn{7}{|l|}{ Marital status } \\
\hline Married & $120(54.05)$ & $102(45.94)$ & \multirow{2}{*}{$<0.001$} & $162(72.97)$ & $60(27.02)$ & \multirow{2}{*}{0.015} \\
\hline Single & $117(71.77)$ & $46(28.22)$ & & $136(83.43)$ & $27(16.56)$ & \\
\hline \multicolumn{7}{|l|}{ Color } \\
\hline White & $110(60.77)$ & $71(39.22)$ & \multirow{4}{*}{0.672} & $138(76.24)$ & $43(23.75)$ & \multirow{4}{*}{0.683} \\
\hline Black & $30(57.69)$ & $22(42.3)$ & & $41(78.84)$ & $11(21.15)$ & \\
\hline Brown & $95(64.18)$ & $53(35.81)$ & & $116(78.37)$ & $32(21.62)$ & \\
\hline Yellow & $2(50)$ & $2(50)$ & & $3(75)$ & $1(25)$ & \\
\hline \multicolumn{7}{|l|}{ Education } \\
\hline Illiterate & $1(33.33)$ & $2(66.66)$ & \multirow{7}{*}{0.593} & $3(100)$ & $0(0)$ & \multirow{7}{*}{0.913} \\
\hline $\begin{array}{l}\text { Incomplete } \\
\text { elementary school }\end{array}$ & $37(67.27)$ & $18(32.72)$ & & $42(76.36)$ & $13(23.63)$ & \\
\hline $\begin{array}{l}\text { Complete } \\
\text { elementary school }\end{array}$ & $10(41.66)$ & $14(58.33)$ & & $13(54.16)$ & $11(45.83)$ & \\
\hline $\begin{array}{l}\text { Incomplete high } \\
\text { school }\end{array}$ & $20(68.96)$ & $9(31.03)$ & & $25(86.2)$ & $4(13.79)$ & \\
\hline $\begin{array}{l}\text { Complete high } \\
\text { school }\end{array}$ & $144(63.15)$ & $84(36.84)$ & & $182(79.82)$ & $46(20.17)$ & \\
\hline $\begin{array}{l}\text { Did not complete } \\
\text { higher education }\end{array}$ & $5(100)$ & $0(0)$ & & $5(100)$ & $0(0)$ & \\
\hline $\begin{array}{l}\text { Completed higher } \\
\text { education }\end{array}$ & $20(48.78)$ & $21(51.21)$ & & $28(68.29)$ & $13(31.7)$ & \\
\hline \multicolumn{7}{|l|}{ Time of delivery } \\
\hline Preterm & $55(77.46)$ & $16(22.53)$ & \multirow{3}{*}{0.024} & $61(85.91)$ & $10(14.08)$ & \multirow{3}{*}{0.044} \\
\hline Term & $163(57.39)$ & $121(42.6)$ & & $216(76.05)$ & 68 (23.95) & \\
\hline Post-term & $19(63.33)$ & $11(36.66)$ & & $21(70)$ & $9(30)$ & \\
\hline \multicolumn{7}{|l|}{ Type of delivery } \\
\hline Cesarean section & $134(65.04)$ & 72 (34.95) & \multirow{2}{*}{0.205} & $165(80.09)$ & $41(19.9)$ & \multirow{2}{*}{0.217} \\
\hline Normal or natural & $103(57.54)$ & $76(42.45)$ & & $133(74.3)$ & $46(25.98)$ & \\
\hline \multicolumn{7}{|l|}{$\begin{array}{l}\text { Complications } \\
\text { during delivery }\end{array}$} \\
\hline No & $183(60)$ & $122(40)$ & \multirow{2}{*}{0.220} & $236(77.37)$ & $69(22.62)$ & \multirow{2}{*}{0.981} \\
\hline Yes & $54(67.5)$ & $26(32.5)$ & & $62(77.5)$ & $18(22.5)$ & \\
\hline \multicolumn{7}{|l|}{ Low birth weight } \\
\hline No & $173(57.66)$ & $127(42.33)$ & \multirow{2}{*}{$<0.001$} & $226(75.33)$ & $74(24.66)$ & \multirow{2}{*}{0.135} \\
\hline Yes & $61(78.2)$ & $17(21.79)$ & & 65 (83.33) & $13(16.66)$ & \\
\hline
\end{tabular}


Table 2. Continuation.

\begin{tabular}{|c|c|c|c|c|c|c|}
\hline & \multicolumn{2}{|c|}{ Exclusive breastfeeding } & \multirow{2}{*}{$p^{*}$} & \multicolumn{2}{|c|}{ Total breastfeeding } & \multirow{2}{*}{$p^{*}$} \\
\hline & $<6$ months & $\geq 6$ months & & $<2$ years & $\geq 2$ years & \\
\hline \multicolumn{7}{|l|}{ Forceps } \\
\hline No & $227(62.19)$ & $138(37.8)$ & \multirow{2}{*}{0.275} & $285(78.08)$ & $80(21.91)$ & \multirow{2}{*}{0.173} \\
\hline Yes & $10(50)$ & $10(50)$ & & $13(65)$ & $7(35)$ & \\
\hline \multicolumn{7}{|l|}{ Used pacifier? } \\
\hline No & $105(53.03)$ & $93(46.96)$ & \multirow{2}{*}{$<0.001$} & $131(66.16)$ & $67(33.83)$ & \multirow{2}{*}{$<0.001$} \\
\hline Yes & $132(70.58)$ & $55(29.41)$ & & $167(89.3)$ & $20(10.69)$ & \\
\hline \multicolumn{7}{|l|}{ Planned pregnancy } \\
\hline No & $138(66.34)$ & 70 (33.65) & \multirow{2}{*}{0.036} & $171(82.21)$ & 37 (17.78) & \multirow{2}{*}{0.014} \\
\hline Yes & 99 (55.93) & $78(44.06)$ & & $127(71.75)$ & $50(28.24)$ & \\
\hline \multicolumn{7}{|l|}{$\begin{array}{l}\text { Breastfeeding in the } \\
\text { first hour of life }\end{array}$} \\
\hline No & $122(73.93)$ & $43(26.06)$ & \multirow{2}{*}{$<0.001$} & $142(86.06)$ & $23(13.93)$ & \multirow{2}{*}{$<0.001$} \\
\hline \multirow[t]{2}{*}{ Yes } & $115(52.27)$ & $105(47.72)$ & & $156(70.9)$ & $64(29.09)$ & \\
\hline & \multicolumn{2}{|c|}{ Median $(95 \% \mathrm{Cl})$} & $p^{* *}$ & \multicolumn{2}{|c|}{ Median $(95 \% \mathrm{Cl})$} & $p^{* *}$ \\
\hline Number of children & $2(2-2)$ & $2(2-2)$ & 0.536 & $2(2-2)$ & $2(2-2)$ & 0.812 \\
\hline Number of abortions & $0(0-0)$ & $0(0-0)$ & 0.905 & $0(0-0)$ & $0(0-0)$ & 0.544 \\
\hline $\begin{array}{l}\text { Age at the time of } \\
\text { delivery }\end{array}$ & $28(26-29)$ & $29(27-31)$ & 0.563 & $28(26-29)$ & $29(27.86-33)$ & 0.304 \\
\hline $\begin{array}{l}\text { Number of people } \\
\text { living in the house }\end{array}$ & $4(4-4)$ & $4(4-4)$ & 0.237 & $4(4-4)$ & $4(4-4)$ & 0.151 \\
\hline Family income & $\begin{array}{r}\mathrm{R} \$ 1,300.00 \\
(\mathrm{R} \$ 1,100.00- \\
\mathrm{R} \$ 1,500.00)\end{array}$ & $\begin{array}{c}R \$ 1,550.00 \\
(R \$ 1,500.00- \\
R \$ 2,000.00)\end{array}$ & 0.104 & $\begin{array}{c}R \$ 1,375.00(R \$ \\
1,145.49-R \$ \\
1,500.00)\end{array}$ & $\begin{array}{r}R \$ 2,000.00 \\
(R \$ 1,500.00- \\
R \$ 2,000.00)\end{array}$ & 0.024 \\
\hline
\end{tabular}

$\mathrm{Cl}$ : confidence interval; * $\chi^{2}$ test; **Wilcoxon rank-sum (Mann-Whitney) test.

had a lower prevalence of early weaning $(\mathrm{OR}=0.665 ; 95 \% \mathrm{CI}$ 0.424-1.042; $\mathrm{p}=0.075$ ) (Table 3).

The final predictors for lower adherence to breastfeeding for 2 years or more included pacifier use, unplanned pregnancy, and no breastfeeding within the first hour after birth. Children using a pacifier exhibited a five times greater risk of breastfeeding for $<2$ years than those who did not use a pacifier $(\mathrm{OR}=4.82 ; 95 \% \mathrm{CI} 2.722-8.54 ; \mathrm{p}<0.001)$. There was a tendency for single mothers to breastfeed for $<2$ years $(\mathrm{OR}=1.714$; 95\%CI 0.99-2.967; $\mathrm{p}=0.054)$. Mothers with planned pregnancies $(\mathrm{OR}=0.517 ; 95 \% \mathrm{CI} 0.305-0.875 ; \mathrm{p}=0.014)$ and those who breastfed in the first hour after birth $(\mathrm{OR}=0.365 ; 95 \% \mathrm{CI}$ $0.208-0.641 ; \mathrm{p}<0.001$ ) had a lower prevalence of early weaning (before 2 years of age) (Table 3 ).

\section{DISCUSSION}

The main observation in the present study was that the percentage of mothers who followed EBF for 6 months and total breastfeeding for 2 years was unsatisfactory. Several factors are associated with reduced breastfeeding duration, some of which are modifiable. The use of a pacifier was a common factor for early interruption of both modalities of breastfeeding.

The prevalence of EBF for $>6$ months was $38.44 \%$, which was considerably lower than the WHO target of $50 \%$ for $2025^{\circ}$. The prevalence of breastfeeding for 2 years or more was $22.6 \%$.

EBF for $<6$ months was associated with low birth weight in this and in other studies. Other studies that corroborate this finding have suggested that newborns with low birth weight spend more time in the intensive care unit or have sucking or 
Table 3. Logistic regression for exclusive breastfeeding for 6 months and total breastfeeding for 2 years.

\begin{tabular}{|c|c|c|}
\hline Characteristics & OR $(95 \% \mathrm{Cl})$ & $\mathrm{p}$ \\
\hline \multicolumn{3}{|c|}{ Exclusive breastfeeding for 6 months } \\
\hline \multicolumn{3}{|l|}{ Marital status } \\
\hline \multirow[b]{2}{*}{ Single } & Ref & \multirow[b]{2}{*}{0.004} \\
\hline & $\begin{array}{c}1.976 \\
(1.245-3.135)\end{array}$ & \\
\hline \multicolumn{3}{|l|}{ Pacifier } \\
\hline \multirow[b]{2}{*}{ Yes } & Ref & \multirow[b]{2}{*}{$<0.001$} \\
\hline & $\begin{array}{c}2.25 \\
(1.436-3.524)\end{array}$ & \\
\hline \multicolumn{3}{|c|}{ Planned pregnancy } \\
\hline \multirow[b]{2}{*}{ Yes } & Ref & \multirow[b]{2}{*}{0.075} \\
\hline & $\begin{array}{c}0.665 \\
(0.424-1.042)\end{array}$ & \\
\hline
\end{tabular}

Breastfeeding in the

first hour of life

\begin{tabular}{l|c|c}
\hline \multirow{3}{*}{ Yes } & Ref & \multirow{2}{*}{0.001} \\
\cline { 2 - 3 } & 0.048 & \multirow{2}{*}{$0.281-0.714)$} \\
\hline
\end{tabular}

\section{Low birth weight}

\begin{tabular}{l|c|c}
\hline \multirow{2}{*}{ Yes } & Ref & \multirow{2}{*}{0.012} \\
\cline { 2 - 3 } & $\begin{array}{c}2.21 \\
(1.192-4.102)\end{array}$ & \\
\multicolumn{2}{c|}{ Total breastfeeding for 2 years }
\end{tabular}

Total breastfeeding for 2 years

Marital status

\begin{tabular}{|c|c|c|}
\hline \multirow[b]{2}{*}{ Single } & Ref & \multirow[b]{2}{*}{0.054} \\
\hline & $\begin{array}{c}1.714 \\
(0.99-2.967)\end{array}$ & \\
\hline \multicolumn{3}{|l|}{ Pacifier } \\
\hline \multirow[b]{2}{*}{ Yes } & Ref & \multirow[b]{2}{*}{$<0.001$} \\
\hline & $\begin{array}{c}4.82 \\
(2.722-8.540)\end{array}$ & \\
\hline \multicolumn{3}{|c|}{ Planned pregnancy } \\
\hline \multirow[b]{2}{*}{ Yes } & Ref & \multirow[b]{2}{*}{0.014} \\
\hline & $\begin{array}{c}0.517 \\
(0.305-0.875)\end{array}$ & \\
\hline
\end{tabular}

Breastfeeding in

the first hour of life

\begin{tabular}{l|c|c}
\hline \multirow{3}{*}{ Yes } & Ref & \multirow{2}{*}{$<0.001$} \\
\cline { 2 - 2 } & 0.365 & \multirow{2}{*}{$(0.208-0.641)$}
\end{tabular}

swallowing difficulties. Moreover, they receive infant formulas earlier than other newborns ${ }^{14,15}$. Maternity hospitals associated with Faculdade de Medicina do $A B C$ participate in the initiative of the Ministry of Health, which prioritizes the use of human milk in nutritional therapy for hospitalized newborns.

Studies have demonstrated the relationship between the use of a pacifier and the reduction of EBF observed in the present study. This finding might be attributed to the fact that the use of a pacifier results in a reduced number of feeds per day, leading to reduced milk production. Moreover, owing to the so-called nozzle confusion, the child can no longer breastfeed correctly because of the pacifier ${ }^{16,17}$. A correlation was observed between increased EBF and a reduction in the use of pacifiers in Brasil, a modifiable element that influences the duration of breastfeeding ${ }^{18}$.

Single mothers exhibited shorter EBF time of up to 6 months, suggesting that social and family support influence breastfeeding duration ${ }^{15}$.

In contrast, mothers who breastfed within the first hour after the birth of their child were more likely to complete EBF for 6 months, which may be attributed to the fact that the interaction between the mother and child in the first hour of life contributes to a greater connection and production of oxytocin, which is essential for milk ejection ${ }^{19}$. This association has already been described in medical literature ${ }^{20}$.

A trend toward reduced duration of EBF was observed in cases of unplanned pregnancy $(\mathrm{p}=0.075)$. A similar finding has been reported in another study and is probably attributed to the fact that mothers who were not prepared for pregnancy were not prepared for breastfeeding as well ${ }^{21}$.

Shorter EBF duration ( $<6$ months) and shorter total breastfeeding duration were associated with the use of pacifiers, as previously reported ${ }^{22}$. A possible explanation for this finding is that the pacifier reduces the number of feeds per day, which leads to reduced milk production ${ }^{23}$. Similarly, women who breastfed during the first hour after the birth of their child exhibited a greater tendency to follow the recommended breastfeeding duration, which can be justified by the greater emotional bond built in the early stages of life, an association described in previous studies ${ }^{11,21}$.

There was a lower tendency for single mothers to breastfeed for 2 or more years. This finding was also associated with exclusive breastfeeding and has been verified in previous studies, reiterating the importance of aggregating social and family element ${ }^{24,25}$.

\section{Limitations}

The present study had some limitations. It was a cross-sectional and observational study. Hence, we could not establish cause-and-consequence relationships. Moreover, the collected 
information was reported by mothers, which may have led to recall bias. No data were collected about the professions of the mothers or the presence of maternity leave, which might be among the causal factors of early interruption of EBF.

Future prospective studies with larger sample sizes should be performed to prove the hypotheses suggested in this cross-sectional study.

\section{CONCLUSIONS}

The prevalence of EBF for 6 months and total breastfeeding for up to 2 years was insufficient in the studied population. Several factors were associated with reduced breastfeeding duration in both the modalities, some of which being modifiable.
Therefore, paying attention to factors that limit breastfeeding may contribute to an increase in the prevalence of breastfeeding in the future.

\section{AUTHORS" CONTRIBUTIONS}

KCT: Conceptualization, Data Curation, Formal Analysis, Writing - Original Draft

Writing - Review \& Editing. LRS: Conceptualization, Data Curation, Writing - Original Draft, Writing - Review \& Editing. LSM: Conceptualization, Data Curation, Writing - Original Draft, Writing - Review \& Editing. ROSS: Conceptualization, Formal Analysis, Writing - Original Draft, Writing - Review \& Editing.

\section{REFERENCES}

1. Shamir R. The benefits of breast feeding. Nestle Nutr Inst Workshop Ser. 2016;86:67-76. https://doi.org/10.1159/000442724

2. Victora CG, Bahl R, Barros AJ, França GV, Horton S, Krasevec $J$, et al. Breastfeeding in the 21st century: epidemiology, mechanisms, and lifelong effect. Lancet. 2016;387(10017):47590. https://doi.org/10.1016/S0140-6736(15)01024-7

3. Krol KM, Grossmann T. Psychological effects of breastfeeding on children and mothers. Bundesgesundheitsblatt Gesundheitsforschung Gesundheitsschutz. 2018;61(8):97785. https://doi.org/10.1007/s00103-018-2769-0

4. Sankar MJ, Sinha B, Chowdhury R, Bhandari N, Taneja S, Martines $J$, et al. Optimal breastfeeding practices and infant and child mortality: a systematic review and meta-analysis. Acta Paediatr. 2015;104(467):3-13. https://doi.org/10.1111/apa.13147

5. World Health Organization. Global strategy for infant and young child feeding [Internet]. Geneva: WHO library cataloguingin-publication data; 2003. 30p. [cited on Sept 23, 2020]. Available from: https://www.who.int/nutrition/publications/ infantfeeding/9241562218/en/

6. UNICEF. Infant and young child feeding [Internet]. UNICEF Data: Monitoring the situation of children and women. 2019 [cited on Jun 30, 2020]. Available from: https://data.unicef. org/topic/nutrition/infant-and-young-child-feeding/

7. Boccolini CS, Boccolini PMM, Monteiro FR, Venâncio SI, Giugliani ERJ. Breastfeeding indicators trends in Brasil for three decades. Rev Saude Publica. 2017;51:108. https://doi. org/10.11606/s1518-8787.2017051000029

8. Brasil, Departamento de Ações Programáticas Estratégicas. II Pesquisa de prevalência de aleitamento materno nas capitais brasileiras e Distrito Federal. Brasília: Ministério da Saúde; 2009. 108p.

9. Venancio SI, Saldiva SRDM, Monteiro CA. Tendência secular da amamentação no Brasil. Rev Saude Publica. 2013;47(6):1205-8. https://doi.org/10.1590/S0034-8910.2013047004676
10. Muchacha M, Mtetwa E. Social and economic barriers to exclusive breast feeding in rural Zimbabwe. Int J MCH AIDS. 2015;3(1):16-21. PMID: 27621982

11. Dharel D, Dhungana R, Basnet S, Gautam S, Dhungana A, Dudani $R$, et al. Breastfeeding practices within the first six months of age in mid-western and eastern regions of Nepal: a health facility-based cross-sectional study. BMC Pregnancy Childbirth. 2020;20(1):59. https://doi.org/10.1186/s12884020-2754-0

12. Wang W, Lau Y, Chow A, Chan KS. Breast-feeding intention, initiation and duration among Hong Kong Chinese women: a prospective longitudinal study. Midwifery. 2014;30(6):678-87. https://doi.org/10.1016/j. midw.2013.07.015

13. Queluz MC, Pereira MJB, dos Santos CB, Leite AM, Ricco RG. Prevalência e determinantes do aleitamento materno exclusivo no município de Serrana, São Paulo, Brasil. Rev Esc Enferm USP. 2012;46(3):537-43. https://doi.org/10.1590/ S0080-62342012000300002

14. Campbell AG, Miranda PY. Breastfeeding trends among very low birth weight, low birth weight, and normal birth weight infants. J Pediatr. 2018;200:71-8. https://doi.org/10.1016/j. jpeds.2018.04.039

15. Jones JR, Kogan MD, Singh GK, Dee DL, Grummer-Strawn LM. Factors associated with exclusive breastfeeding in the United States. Pediatrics. 2011;128(6):1117-25. https://doi. org/10.1542/peds.2011-0841

16. Boccolini CS, Carvalho ML, Oliveira MI. Factors associated with exclusive breastfeeding in the first six months of life in Brasil: a systematic review. Rev Saude Publica. 2015;49:91. https://doi.org/10.1590/S0034-8910.2015049005971

17. Balogun OO, Dagvadorj A, Anigo KM, Ota E, Sasaki S. Factors influencing breastfeeding exclusivity during the first 6 months of life in developing countries: a quantitative and qualitative systematic review. Matern Child Nutr. 2015;11(4):433-51. https://doi.org/10.1111/mcn.12180 
18. Buccini G, Pérez-Escamilla R, D'Aquino Benicio MH, Justo Giugliani ER, Isoyama Venancio S. Exclusive breastfeeding changes in Brasil attributable to pacifier use. PLoS One. 2018;13(12):e0208261. https://doi.org/10.1371/journal. pone.0208261

19. Chaves RG, Lamounier JA, César CC. Fatores associados com a duração do aleitamento materno. J Pediatr. 2007;83(3):241-6. http://doi.org/10.2223/JPED.1610

20. Andrade HS, Pessoa RA, Donizete LCV. Fatores relacionados ao desmame precoce do aleitamento materno. Rev Bras Med Fam Comunidade. 2018;13(40):1-11. https://doi.org/10.5712/ rbmfc13(40)1698

21. Yılmaz E, Doğa Öcal F, Vural Yılmaz Z, Ceyhan M, Kara OF, Küçüközkan T. Early initiation and exclusive breastfeeding: factors influencing the attitudes of mothers who gave birth in a baby-friendly hospital. Turk J Obstet Gynecol. 2017;14(1):1-9. https://doi.org/10.4274/tjod.90018
22. Farias SE, Wisniewsk D. Aleitamento materno $x$ desmame precoce. Rev Uningá. 2015;22(1):14-9.

23. Buccini GS, Pérez-Escamilla R, Paulino LM, Araújo CL, Venancio SI. Pacifier use and interruption of exclusive breastfeeding: systematic review and meta-analysis. Matern Child Nutr. 2017;13(3):e12384. https://doi.org/10.1111/mcn.12384

24. Cascone D, Tomassoni D, Napolitano F, Di Giuseppe G. Evaluation of knowledge, attitudes, and practices about exclusive breastfeeding among women in Italy. Int J Environ Res Public Health. 2019;16(12):2118. https://doi.org/10.3390/ ijerph16122118

25. Mahesh PKB, Gunathunga MW, Arnold SM, Jayasinghe $C$, Pathirana S, Makarim MF, et al. Effectiveness of targeting fathers for breastfeeding promotion: systematic review and meta-analysis. BMC Public Health. 2018;18(1):1140. https:// doi.org/10.1186/s12889-018-6037-x 